\title{
The Macroeconomics of International Financial Trade
}

\author{
Philip R. Lane * \\ Institute for International Integration Studies (IIIS) \\ and Economics Department, Trinity College Dublin \\ and CEPR
}

August 2003

\begin{abstract}
A driving factor in any open-economy macroeconomics model is the degree of international financial integration. This suggests that understanding the sources of the recent explosive growth in cross-border asset trade and the impact of the upscaling in gross and net international investment positions on key open-economy macroeconomic variables such as the trade balance and the real exchange rate is critically important for policy analysis. Accordingly, the goal of this paper is to highlight some of the main results emerging from this fast-expanding research field.
\end{abstract}

\footnotetext{
*Email: plane@tcd.ie. This paper is forthcoming in Exchange Rates and Capital Movements (Rebecca Driver, Peter Sinclair, Christoph Thoenissen, eds), Routledge, 2004. This paper draws heavily on my joint work with Gian Maria Milesi-Ferretti. Useful comments were also received at CCBS workshops. I am grateful for the support provided by the IIIS. This paper is also part of a research network on 'The Analysis of International Capital Markets: Understanding Europe's Role in the Global Economy', funded by the European Commission under the Research Training Network Programme (Contract No. HPRN-CT-1999-00067) .
} 


\section{Introduction}

In this paper, I provide a selective overview of recent research on the spectacular growth in international financial trade and its implications for the macroeconomic behaviour of open economies. The motivation for this research topic is quite basic, in that a driving factor in any open-economy macroeconomics model is the degree of international financial integration. This suggests that understanding the sources of the recent explosive growth in cross-border asset trade and the impact of the upscaling in gross and net international investment positions on key open-economy macroeconomic variables such as the trade balance and the real exchange rate is critically important for policy analysis. Accordingly, the goal of this paper is to introduce the reader to some of the main results emerging from this fast-expanding research field. However, it is beyond the scope of this paper to provide a comprehensive survey of the literature: the following material is intentionally selective and indeed heavily draws on my ongoing collaboration with Gian Maria Milesi-Ferretti of the International Monetary Fund.

The rest of the paper is organized as follows. Section 2 surveys the determinants of the growth in international financial trade: both the scale of gross investment positions and the emergence of large net foreign asset imbalances. The macroeconomic implications are explored in Section 3, in terms of the impact of net imbalances on the trade balance, the real exchange rate and real interest rate differentials. In addition, the potential impact of large cross-holdings on patterns in risk-sharing, growth and business cycles is also briefly reviewed. Section 4 offers some concluding remarks.

\section{The Rise in International Financial Trade}

In this section, we first briefly discuss data issues before turning to the empirical analysis of gross and net foreign asset positions.

\subsection{Data Sources}

Data limitations provide one reason why quantitative analysis of international financial trade has been relatively limited. This is especially the case, if one wishes to focus on accumulated stock holdings, rather than just examining international financial flows. Some countries (e.g. the United States, the United Kingdom and Canada) have long provided high-quality national data on foreign assets and liabilities. However, the International Monetary Fund only began reporting the details of international investment positions for a small number of countries in 1997. Its coverage has broadened since then but, especially for developing countries, its data do 
not go far back in time.

To redress this gap, Lane and Milesi-Ferretti (2001) set out to construct estimates of gross foreign assets and foreign liabilities for a large number of industrial and developing countries over 1970-1998. In addition to the broad aggregates, the composition of the international balance sheet (debt, portfolio equity, FDI) was also addressed. The stock estimates were derived by cumulating gross financial flows but corrected for the valuation changes that result from movements in financial markets, currencies and price levels. Moreover, it is also important to allow for once-off capital transfers and the impact of debt reduction and debt cancellation programmes for some countries.

The importance of valuation changes in driving the evolution of net foreign asset positions is well illustrated by Table 1 (adapted from Lane and Milesi-Ferretti 2001a), which shows that the correlation between the current account and the change in the net foreign asset position is typically far from unity. As such, the simplistic method of capturing net foreign asset positions by simply cumulating current account imbalances can prove highly misleading.

\subsection{Determinants of Gross International Investment Positions}

As is emphasised by Lane (2000), Lane and Milesi-Ferretti (2001a, 2001b, 2003a) and Obstfeld and Taylor (2003), the size of international balance sheets have grown very rapidly in recent decades. Although many countries display net foreign asset positions that are close to zero, this is consistent with having a large gross foreign asset position that is counterbalanced by offsetting gross foreign liabilities.

Even if net positions are small, large gross positions have important macroeconomic implications. First, the potential for international risk-sharing is largely a function of the scale of international balance sheets. For instance, domestic risks can be partly laid off by issuing statecontingent foreign liabilities - accomplished, for example, by the sale of domestic equities to external investors. In the other direction, holding foreign assets provides diversification, since the returns on these foreign assets will be determined by external events. Of course, the precise mechanics of risk sharing will depend on the composition of the international balance sheet as between debt and equity-type investments and also on the mix between assets and liabilities that are denominated in domestic currency versus foreign currencies.

Second, gross positions also affect the relation between asset price fluctuations (including currency fluctuations) and macroeconomic variables. The larger the scale of the international balance sheet, the more important are re-valuation effects. To give a simple example, if a country holds $\$ 1$ billion in dollar-denominated assets, it is much more exposed to shifts in the value of 
the dollar and in US financial markets than if its position is only $\$ 100$ million. In this way, the growth in international financial positions strengthens international linkages across economies through this revaluation mechanism.

Third, international asset cross-holdings may also influence the determination of asset prices. To the extent that wealth effects are important for asset pricing, the closer correlation in wealth dynamics across investors of different nationalities that is induced by greater international diversification may also generate higher international comovement in asset prices.

Fourth, the internationalization of capital ownership may also have political economy implications in that it may be increasingly difficult to distinguish between domestic and foreign owners of capital. In turn, this feeds into debates about optimal and feasible tax structures and international regulation of corporations and financial markets.

Finally, a high level of international financial integration may also alter long-run growth potential. This may be the case for a number of reasons. First, international risk-sharing permits domestic investors to take on riskier projects that may promise higher returns. Second, the internationalization of the capital stock may weaken incentives to over-tax or over-regulate investment. Third, the discipline effect of open capital markets may also improve monitoring and increase the efficiency of capital allocation. On the other side, however, a poor regulatory structure and/or an exposed external capital structure may adversely affect economic performance by permitting overborrowing and increasing vulnerability to output-destroying financial crises.

For these reasons, it is important to understand the determinants of the scale and composition of international balance sheets. Lane and Milesi-Ferretti (2003a) studied the dynamics of the level of international financial integration for a sample of industrial countries over 1983-2001. The volume-based measure considered is

$$
I F I G D P_{i t}=\frac{\left(F A_{i t}+F L_{i t}\right)}{G D P_{i t}}
$$

where $F A_{i t}, F L_{i t}$ denote the levels of gross foreign assets and gross foreign liabilities respectively. The growth in this ratio is modeled as

$$
\Delta I F I G D P_{i t}=\alpha_{i}+\gamma * X_{i t}+\beta * \Delta Z_{i t}+\varepsilon_{i t}
$$

where $X_{i t}, Z_{i t}$ are a set of country- and time-varying determinants. Table 2 shows the results for a panel of industrial countries over 1983-2001. At a broad level, the most important covariates of the growth in international financial integration are: (a) the growth in international trade in goods and services; (b) rising output per capita; and (c) domestic financial and stockmarket development. While the importance of each of these variables is intuitively appealing, an important direction for future research is to sort out the lines of causality in the dynamic relation 
between these factors and the growth in international financial integration.

Drawing on Lane and Milesi-Ferretti (2003a), Table 2 also shows that the external liberalization index loses its explanatory power once other determinants are included in the specification: this is attributable to the fact that the process of opening capital accounts in the industrial countries was largely completed by the end of the 1980s, whereas the most rapid growth in international financial cross-trade took place in the late 1990s. The result that privatization, all else being equal, is associated with a lower value of international financial integration is somewhat surprising: one candidate explanation is that the terms of privatization programmes favour domestic investors and induce a greater home bias in investment patterns. In terms of composition, Lane and Milesi-Ferretti (2003a) find that the growth of the domestic stockmarket is the single most important factor associated with an increase in the ratio of equity to debt positions in the aggregate international balance sheet.

Employing the dataset developed by Lane and Milesi-Ferretti (2001a), Lane and MilesiFerretti (2001b) find that trade openness is highly important in explaining the level of aggregate external liabilities for developing countries and also raises the ratio of equity to debt liabilities. Another significant finding from that study is that ratio of FDI to total private liabilities negatively covaries with country size: smaller countries disproportionately rely on FDI as source of external investment.

Clearly, much remains to be done to gain a comprehensive understanding of the growth in international cross-border financial holdings and the determination of the relative contributions of debt and equity (both portfolio and FDI) in the overall external capital structure. As time elapses and data collection efforts intensify, more can be done to test various hypotheses about this phenomenon. In one direction, Lane and Milesi-Ferretti (2003b) explore the geographical composition of international investment positions, drawing on the recently-released Comprehensive Portfolio Investment Survey that is coordinated by the International Monetary Fund.

\subsection{Determinants of Net Foreign Asset Positions}

Although much has been written about the cyclical behaviour of the current account, relatively less is known about the long-run behaviour of net foreign asset positions. This is unsatisfactory, since recent decades have seen the emergence of persistent net foreign asset imbalances that represent significant asymmetries in the world economy. As will be explored later in this paper, non-zero long-term net foreign asset positions have implications for the behaviour of trade balances, real exchange rates and real interest rates. In addition, these asymmetries influence the transmission of monetary and fiscal policies and the calculus involved in proposals to improve 
international policy coordination.

To gain some insight into the empirical determination of long-run net foreign asset positions, Lane and Milesi-Ferretti (2002a) estimate a parsimonious fixed-effects panel model for samples of industrial and developing countries. Three factors are considered: relative output per capita; the level of public debt; and demographic structure. In general, we may expect a long-term increase in output per capita to be associated with an improvement in the net foreign asset position savings may increase, while the decline in the domestic marginal product of capital may induce a switch towards overseas investment. However, at least for developing countries, an increase in output per capita may relax binding credit constraints, such that it permits an increase in external borrowing - for these countries, the net correlation may actually be negative.

Public debt is included, since a failure of Ricardian Equivalence implies a 'twin debts' outcome - the higher is public debt, the larger also is net external debt. Finally, demography may influence the net foreign asset positions, both via its impact on the rate of asset accumulation and also on the rate of domestic capital formation. For instance, a country with a large cohort in the 40-65 age bracket may accumulate net foreign assets, as the savings rate increases in anticipation of retirement and the investment rate falls on account of the relative scarcity of young workers.

Based on Lane and Milesi-Ferretti (2002a), Tables 3 and 4 report the results of the panel estimation of the determinants of net foreign asset positions for industrial and developing country samples respectively. For the industrial country sample, Table 3 shows that that richer industrial countries indeed have more positive net foreign asset positions, with the age profile of the population also exerting an influence and that higher public debt is associated with some deterioration in the external account.

For the developing country sample, Table 4 shows that the relation between output per capita and the net foreign asset position is in fact negative: higher output is associated with an increase in net external liabilities. In addition, there is a high "pass-through" from net government liabilities to net external liabilities. Both of these results are consistent with the presence of external and internal credit constraints in developing countries. The demographic structure of developing countries again turns out to influence the net foreign asset position.

Importantly, these long-run factors are important for the overall dynamics of the net foreign asset position. Again based on Lane and Milesi-Ferretti (2002a), Table 5 reports the adjustment coefficient from an "error correction mechanism" (ECM) representation

$$
\Delta N F A_{i t}=-\delta\left(N F A_{i t-1}-N F A_{i t-1}^{*}\right)+\beta * Z_{i t}+\varepsilon_{i t}
$$

where $N F A_{i t}^{*}$ is the desired long-run net foreign asset position and the control factors $Z_{i t}$ (not 
reported) include innovations to the factors driving $N F A_{i t}^{*}$ and a lag of the dependent variable.This simple ECM equation has good explanatory power: Lane and Milesi-Ferretti (2002a) show its capability to track actual net foreign asset positions for a wide range of industrial countries.

In summary, this section has addressed the factors underlying the growth in the scale of international investment cross-holdings and the determinants of net foreign asset positions. In the next section, we ask whether the increase in gross and net international financial trade has implications for the macroeconomic behaviour of open economies.

\section{Macroeconomic Implications of International Financial Trade}

In this section, we turn to drawing out the macroeconomic implications of the rise in internatonal financial trade and the emergence of large divergences in net foreign asset positions between creditor and debtor countries. We first consider trade balances before turning to real exchange rates and real interest rate differentials. We then briefly consider the relations between financial globalization and international risk sharing, long-run growth performance and business cycle analysis.

\subsection{Trade Balance Adjustment}

For sustainability, the trade balance must adjust to reflect the value of the net foreign asset position. Following Lane and Milesi-Ferretti (2002a, 2002b), we can write the ratio of the trade balance to GDP as

$$
t b_{t}=-\left[\frac{r_{t}-g_{t}}{1+g_{t}}\right] f_{t-1}+\varepsilon_{t} \equiv \Psi_{t}+\varepsilon_{t}
$$

where $f_{t}$ is the net foreign asset position, $r_{t}$ is the (common) rate of return on foreign assets and liabilities and $g_{t}$ is the GDP growth rate. The disturbance term captures temporary deviations from this long-run value, reflecting cyclical disturbances and shifts in the desired net foreign asset position. If the rate of return exceeds the output growth rate $\left(r_{t}>g_{t}\right)$, then a long-run creditor country can run persistent trade deficits, while a debtor country must run trade surpluses.

The trade balance adjustment that is required depends on the rate of return, which in turn should reflect the composition of the international balance sheet. To develop this point, let us now relax the assumption that foreign assets and liabilities earn a common rate of return. We 
can re-write equation $(\mathrm{X})$ as

$$
t b_{t}=-\left\{\left[\frac{r_{t}^{A}-g_{t}}{1+g_{t}}\right] f_{t-1}+\left[\frac{r_{t}^{L}-r_{t}^{A}}{1+g_{t}}\right] f l_{t-1}\right\}+\varepsilon_{t}
$$

where $r_{t}^{A}, r_{t}^{L}$ denote the rates of return on gross assets and gross liabilities $\left(f l_{t}\right)$ respectively. For a debtor nation, a larger trade surplus must be maintained, the greater is the positive differential $\left(r_{t}^{L}>r_{t}^{A}\right)$. Conversely, a debtor country need not run a trade surplus at all if it earns sufficiently more on its foreign assets than it pays out on its foreign liabilities $\left(r_{t}^{L}<<r_{t}^{A}\right)$. For instance, a country that primarily issues foreign liabilities in the form of short-term liquid debt securities but invests overseas in higher-risk higher-return foreign equity assets may find itself in this fortunate position. ${ }^{1}$

Lane and Milesi-Ferretti (2002b) confirm that equation (5) has empirical relevance: they find that $\left(t b_{t}, \Psi_{t}\right)$ are cointegrated for a sample of industrial countries, with a growth in long-term investment income or capital gains associated with a long-term decline in the trade balance. In this regard, it is important to underline the importance of rates of return and growth rates in intermediating the relation between net foreign assets and the trade balance: the cross-country correlation between the 'raw' net foreign asset position and the trade balance is relatively weak, in view of the substantial variation in rates of return and output growth rates. For instance, drawing on Lane and Milesi-Ferretti (2002b), Table 6 shows the variation in rates of return on foreign assets and foreign liabilities for a selection of industrial countries over 1993-1998.

\subsection{Real Exchange Rates}

A classical principle in international economics is the "transfer problem": a country that must engineer a net resource outflow (e.g. war reparations or investment income payments to foreign investors) may need an equilibrium real exchange rate depreciation in order to achieve the required re-structuring of the domestic economy. Lane and Milesi-Ferretti (2001b, 2002b) provide a range of estimates for the size of the "transfer problem" effect and show that the magnitudes are typically quite substantial, especially for the larger economies (US, Japan, Euroland).

Table 7 shows the baseline results from Lane and Milesi-Ferretti (2001b) which models the long-run CPI-based real exchange rate as depending on the net foreign asset position, relative output per capita and the terms of trade. In column (1), all countries are pooled together, whereas columns (2) and (3) report results for the separate industrial and developing country subsamples. Across the specifications, a significant association between net foreign assets and real exchange rates is evident: more indebted countries have more depreciated real exchange rates.

\footnotetext{
${ }^{1}$ However, such a country may leave itself exposed to a 'run' problem if creditors refuse to roll-over the short-term liquid liabilities.
} 
Importantly, the evidence in Lane and Milesi-Ferretti (2001b, 2002b) is that the net foreign asset position influences the real exchange rate via the relative price of nontradables: it cannot be attributed to endogenous movements in the terms of trade. Further analysis in those papers shows that the magnitude of the transfer problem intuitively covaries with country size: the real exchange rate adjustment required for a large, closed economy is much bigger than for a smaller externally-orientated economy (see Figure 1, derived from Lane and Milesi-Ferretti 2002b). For a sample of industrial countries, Lane and Milesi-Ferretti (2002b) also take into account that rates of return and output growth rates influence the required trade balance adjustment for a given

long-term net foreign asset position and show that this correction strengthens the estimated relation between the trade balance and the real exchange rate.

\subsection{Real Interest Rate Differentials}

Lane and Milesi-Ferretti (2002a) also study the comovement of real interest rate differentials and net foreign asset positions. In the portfolio-balance literature, it is hypothesised that a net debtor country must offer higher returns in order to induce global investors to hold its liabilities (see Frankel and Rose 1995 for a review). Table 8 reports the panel fixed-effects results: in panel A, all countries are included and the time dummies soak up the "world real interest rate" that is common to all countries; in panel $\mathrm{B}$, the dependent variable is the real interest rate differential vis-à-vis the US. In some of the specifications, we also control for the level of public debt and the rate of real exchange rate appreciation. The findings are quite suggestive: there is indeed some support for a portfolio-balance effect, with net creditor countries enjoying lower real interest rates than net debtors. The negative cross-sectional correlation is also evident in the scatter plot in Figure 2, also derived from Lane and Milesi-Ferretti (2002a).

In this subsection, we have focused on long-run relations in the data. Exchange rate adjustment to long-run equilibrium is unlikely to be perfectly smooth. Obstfeld and Rogoff (2001) analyze a number of scenarios for the dollar correction required in the event that global investors turn against funding the US external deficit. An important lesson from that research is that the existence of nominal rigidities sharply magnifies the required scale of short-run nominal depreciation in the event of a sharp reversal in capital flows.

\subsection{International Risk Sharing}

As was highlighted in section 2, an increase in the scale of international asset cross-holdings might be expected to lead to more international risk-sharing via a greater level of wealth diversification. Some studies have looked at this question in a partial and indirect manner by asking whether 
national incomes (GNP levels) are insulated from domestic output (GDP) shocks. For instance, in a study of the Irish economy, Lane (1998) finds that indeed the net factor income outflows are procyclical: GNP is less affected by cyclical fluctuations than GDP. However, for a broader sample of OECD countries, Sorensen and Yosha (1998) and Lane (2001) find little evidence of a smoothing role for international investment income flows.

A limitation of that approach is that risk-sharing may take place through the movements of capital gains rather than via investment income. Lane and Milesi-Ferretti (2003a) show that holding overseas assets indeed diversifies against domestic financial risks: although the correlations are typically positive, the degree of return comovement is far from perfectly correlated. In general, the capital gains component is far more volatile than the investment income component in overall financial returns, so that it is not too surprising that this factor is central in assessing the degree of diversification that is afforded by international financial integration. However, Sorensen et al (2002) find that the investment income channel also becomes stronger, the greater is the degree of financial integration: the capacity of investment income flows to smooth GDP shocks is increasing in the level of foreign asset holdings.

Of course, the flip-side of acquiring insulation from domestic disturbances is greater exposure to externally-generated shocks. As is highlighted by Begg et al (2002), the sharp reversals in US equity markets and in corporate profitability in 2000-2001 were quickly transmitted to Europe, in part due to the rapid acquisition of US assets by European investors during the late 1990s. It is also the case that financial integration alters the allocative impact of financial bubbles Ventura (2002) explores the inter-relation between bubbles and international capital flows.

\subsection{Economic Growth}

During the 1990s, there was an extensive literature that attempted to identify the impact of capital account liberalization for economic growth, typically finding only weak effects (see Eichengreen 2002 for a review). In general, this is not too surprising since any positive effect may be over-shadowed in the data by the impact of growth-impairing financial crises.

More recently, a number of studies have rather explored the relation between volume-based measures of financial integration and economic growth (Prased et al 2003, Durham 2003, O'Donnell 2003). These studies use variables similar to the IFIGDP measure defined in equation (1) above. Consistent with the earlier literature, the IMF study carried out by Prasad et al (2003) also finds

it difficult to detect a strong and robust causal relationship between financial integration and economic growth. However, there is some support for nonlinearity in the relationship: above a certain threshold level of domestic absorptive capacity, greater financial integration does indeed 
deliver high growth and lower volatility if an appropriate policy framework is in place.

Overall, it is perhaps too early to reach firm conclusions about the growth impact of greater financial integration. As the robustness of domestic financial sectors and regulatory institutions improve and adapt to a globalized financial system, the inherent capacity of financial integration to improve international resource allocation may come to the fore and deliver faster growth to capital-importing countries. Moreover, as is highlighted by Gourinchas and Jeanne (2003), the most significant gains from financial integration may accrue through indirect channels: for instance, by shifting the domestic political equilibrium in the direction of a more investmentfriendly policy regime.

\subsection{Business Cycle Analysis}

Significant non-zero net foreign asset positions also have implications for business cycles and the analysis of macroeconomic stabilisation policies. ${ }^{2}$ Accumulated imbalances - regardless of their origin - may be important, since exchange rate and asset price fluctuations then also operate via a revaluation channel on the value of foreign assets and liabilities. For instance, Benigno (2001) shows that the business cycle response to shocks is quantitatively quite different if the initial net foreign asset position is say 30-50 percent of GDP rather than zero as is assumed in most of the literature.

Moreover, the asymmetry created by non-zero net foreign asset positions also implies potentially large gains to international policy coordination. In Benigno's model, for zero initial net foreign asset positions, the first best can be well approximated a policy of targeting domestic producer price inflation. ${ }^{3}$ However, such a policy induces excessive volatility in interest rates and hence inefficient cross-country wealth redistributions if initial net foreign asset positions are non-zero and policy coordination in this case can substantially improve welfare.

Tille (2003) provides a simple example about the impact of increasing financial integration on the transmission of exchange rate movements. Consider two cases with the same negative net foreign asset position of minus $€ 100$ billion. In case A, foreign assets and liabilities are $€ 100$ billion and $€ 200$ billion respectively; in case $B$, these stand at $€ 1,000$ billion and $€ 1,100$ billion. Let all foreign assets and liabilities be denominated in the domestic currency. A ten percent appreciation reduces the value of foreign assets by the same proportion in both cases. However, in case $\mathrm{A}$, this translates into a wealth loss of $€ 10$ billion, whereas it represents a wealth decline of $€ 100$ billion in case B : a very significant difference, with corresponding implications for

\footnotetext{
${ }^{2}$ Lane and Ganelli (2003) provide a more extensive discussion of this issue.

${ }^{3}$ This is the optimal policy under complete financial integration. If initial net foreign asset positions are zero, it is also not far from the optimum with bond-only international asset trade.
} 
consumption and investment behaviour.

It should be recognized that a significant net external liability position also leaves a country vulnerable to a financing crisis, which can in itself be a source of business cycle volatility. In turn, a sharp turnaround in the trade balance may require a large real depreciation, especially in the presence of nominal rigidities. Such sudden stops in capital inflows have been a recurrent problem for emerging market economies in recent years. There is by now a large literature on the macroeconomics of 'liability dollarization' in developing countries (see, amongst others, Devereux and Lane 2003 and Lane 2003). However, as indicated in the previous subsection, a financing crisis scenario is also potentially relevant for major industrial nations such as the United States, even if the currency composition profile of foreign liabilities is less risky for these countries.

In summary, to fully incorporate the implications of growing international balance sheets into the "new open economy macroeconomics" modelling framework, more attention needs to be paid to the theoretical treatment of asset accumulation. It would be desirable to also allow for international trade in equities in addition to trade in bonds, without going all the way to a complete asset markets structure. ${ }^{4}$ In related fashion, it may also be useful to re-incorporate portfolio-balance considerations into the baseline open-economy macroeconomic model.

\section{Conclusions}

This paper has provided a tour d'horizon of some of the main research strands that have been pursued in analyzing the macroeconomics of the recent rapid growth in international financial trade. As has been evident throughout the discussion, this research programme is quite immature. In part, this is due to the fact that the process of financial globalization is still in its early stages. As more data accumulates, more insights can be gained as to how macroeconomic relations are affected by international financial integration and how adjustment to larger net foreign asset positions imbalances will play out. For these reasons, this is likely to be an extremely active research field in the coming years and one that also has high relevance for policymakers.

\section{References}

Albuquerque, Rui. 2003. The Composition of International Capital Flows: Risk-Sharing Through Foreign Direct Investment. Journal of International Economics, forthcoming.

\footnotetext{
${ }^{4}$ See also Heathcote and Perri (2002) who focus more on the implications of financial globalization for models in the international real business cycle tradition.
} 
Begg, David, Fabio Canova, Antonio Fatas, Paul de Grauwe and Philip R. Lane, 2002. Surviving the Slowdown. Monitoring the European Central Bank 4, Centre for Economic Policy Research.

Benigno, Pierpaolo, 2001. Price Stability with Imperfect Financial Integration. Mimeo, New York University.

Devereux, Michael B. and Philip R. Lane, 2003. Exchange Rates and Monetary Policy for Emerging Market Economies. Mimeo, University of British Columbia and Trinity College Dublin.

Durham, J. Benson, 2003. Foreign Portfolio Investment, Foreign Bank Lending, and Economic Growth. International Finance Discussion Paper No. 2003-757, Board of Governors of the Federal Reserve System.

Eichengreen, Barry, 2002. Capital Account Liberalization: What Do Cross-Country Studies Tell Us? World Bank Economic Review, 15(3), 341-365.

Frankel, Jeffrey and Andrew K. Rose, 1995. Empirical Research on Nominal Exchange Rates. In Handbook of International Economics. Vol 3. G. Grossman and K. Rogoff (eds). Amsterdam: North-Holland.

Gourinchas, Pierre-Olivier and Olivier Jeanne, 2003. The Elusive Gains from International Financial Integration. CEPR Discussion Paper No. 3902.

Heathcote, Jonathan and Fabrizio Perri, 2002. Financial Globalization and Real Regionalization. Mimeo, New York University.

Lane, Philip R., 1998. International Diversification and the Irish Economy. Economic and Social Review 31, 37-54.

Lane, Philip R., 2000. International Investment Positions: A Cross-Sectional Analysis. Journal of International Money and Finance, 19(4), 513-534.

Lane, Philip R., 2003. Business Cycles and Macroeconomic Policy in Emerging Market Economies. International Finance, 6(1), 89-108.

Lane, Philip R. and Giovanni Ganelli, 2003. Dynamic General Equilibrium Analysis: The Open Economy Dimension. In S. Altug, J. Chaddha, C. Nolan (eds) Elements in Dynamic Macroeconomic Analysis, Cambridge University Press, forthcoming.. 
Lane, Philip R. and Gian Maria Milesi-Ferretti, 2001a. The External Wealth of Nations: Measures of Foreign Assets and Liabilities for Industrial and Developing Countries. Journal of International Economics, 55, 263-294.

Lane, Philip R. and Gian Maria Milesi-Ferretti, 2001b. External Capital Structure: Theory and Evidence. In (H. Siebert, ed.) The World's New Financial Landscape: Challenges for Economic Policy. Springer-Verlag, Berlin.

Lane, Philip R. and Gian Maria Milesi-Ferretti, 2001c. The Transfer Problem Revisited: Net Foreign Assets and Long-Run Real Exchange Rates. CEPR Discussion Paper No. 2511.

Lane, Philip R. and Gian Maria Milesi-Ferretti, 2002a. Long-Term Capital Movements. NBER Macroeconomics Annual 16, 73-116.

Lane, Philip R. and Gian Maria Milesi-Ferretti, 2002b. External Wealth, the Trade Balance and the Real Exchange Rate. European Economic Review, 46, 1049-1071.

Lane, Philip R. and Gian Maria Milesi-Ferretti, 2003a. International Financial Integration. International Monetary Fund Staff Papers. Forthcoming.

Lane, Philip R. and Gian Maria Milesi-Ferretti, 2003b. International Investment Patterns. Mimeo, Trinity College Dublin and International Monetary Fund.

O’Donnell, Barry, 2003. International Financial Integration and Economic Performance. PhD Dissertation, Trinity College Dublin.

Obstfeld, Maurice and Kenneth Rogoff, 2001. Perspectives on OECD Capital Market Integration: Implications for U.S. Current Account Adjustment. In Global Economic Integration: Opportunities and Challenges, Federal Reserve Bank of Kansas City, 169-208.

Obstfeld, M., and Alan M. Taylor, 2003. Global Capital Markets: Integration, Crisis, and Growth. Cambridge: Cambridge University Press. Forthcoming.

Prasad, Eswar, Kenneth Rogoff, Shang-Jin Wei, and M. Ayhan Kose, 2003. The Effects of Financial Globalization on Developing Countries: Some Empirical Evidence. IMF Occasional Paper No. 220, forthcoming.

Sorensen, Bent E. and Oved Yosha, 1998. International Risk Sharing and European Monetary Unification. Journal of International Economics 45, 211-238.

Sorensen, Bent E., Yi-Tsung Wu and Oved Yosha, 2002. Home Bias and International Risk Sharing: Twins Separated at Birth. Mimeo, University of Houston. 
Tille, Cedric, 2003. The Impact of Exchange Rate Movements on U.S. Foreign Debt. Current Issues in Economics and Finance, 9(1), Federal Reserve Bank of New York.

Ventura, Jaume, 2002. Bubbles and Capital Flows. Mimeo, CREI. 
Table 1: Correlation between Current Account and Change in Net Foreign Asset Position

\begin{tabular}{ll}
\hline & $\rho(C A, \triangle N F A)$ \\
\hline USA & 0.53 \\
UK & 0.53 \\
Austria & 0.87 \\
Denmark & 0.29 \\
France & 0.44 \\
Germany & 0.89 \\
Italy & 0.95 \\
Netherlands & -0.14 \\
Norway & 0.93 \\
Sweden & 0.66 \\
Switzerland & -0.63 \\
Canada & 0.6 \\
Japan & 0.82 \\
Finland & 0.17 \\
Greece & 0.89 \\
Iceland & 0.98 \\
Ireland & 0.99 \\
Portugal & 0.98 \\
Spain & 0.51 \\
Australia & 0.34 \\
New Zealand & 0.22 \\
\hline
\end{tabular}

Source: Lane and Milesi-Ferretti (2001a). $C A$ is current account to GDP ratio; $\triangle N F A$ is first difference of the ratio of net foreign assets to GDP. 
Table 2: Determinants of International Financial Integration, 1982-2001

\begin{tabular}{|c|c|c|c|c|c|c|c|}
\hline & $(1)$ & $(2)$ & $(3)$ & $(4)$ & $(5)$ & $(6)$ & $(7)$ \\
\hline External Liberalization & $\begin{array}{l}0.29 \\
(5.3)^{* * *}\end{array}$ & $\begin{array}{l}0.06 \\
(.69)\end{array}$ & $\begin{array}{l}0.04 \\
(.5)\end{array}$ & $\begin{array}{l}-0.05 \\
(.5)\end{array}$ & $\begin{array}{l}-0.06 \\
(.6)\end{array}$ & $\begin{array}{l}0.08 \\
(.8)\end{array}$ & $\begin{array}{l}0.05 \\
(.5)\end{array}$ \\
\hline Trade openness & & $\begin{array}{l}4.18 \\
(3.2)^{* * *}\end{array}$ & $\begin{array}{l}4.95 \\
(3.7)^{* * *}\end{array}$ & $\begin{array}{l}3.08 \\
(3.71)^{* * *}\end{array}$ & $\begin{array}{l}3.89 \\
(4.5)^{* * *}\end{array}$ & $\begin{array}{l}3.29 \\
(3.63)^{* * *}\end{array}$ & $\begin{array}{l}2.72 \\
(3.01)^{* * *}\end{array}$ \\
\hline Log GDP per capita & & & $\begin{array}{l}2.65 \\
(2.5)^{* *}\end{array}$ & $\begin{array}{l}1.56 \\
(1.97)^{*}\end{array}$ & $\begin{array}{l}2.76 \\
(3.51)^{* * *}\end{array}$ & $\begin{array}{l}2.82 \\
(4.31)^{* * *}\end{array}$ & $\begin{array}{l}2.71 \\
(4.06)^{* * *}\end{array}$ \\
\hline Financial Depth & & & & $\begin{array}{l}0.24 \\
(1.58)\end{array}$ & $\begin{array}{l}0.56 \\
(1.68)\end{array}$ & $\begin{array}{l}0.62 \\
(1.88)^{*}\end{array}$ & $\begin{array}{l}0.75 \\
(2.37)^{* *}\end{array}$ \\
\hline Stock market capitalization & & & & $\begin{array}{l}1.27 \\
(5.86)^{* * *}\end{array}$ & $\begin{array}{l}1.3 \\
(6.18)^{* * *}\end{array}$ & $\begin{array}{l}1.32 \\
(6.35)^{* * *}\end{array}$ & $\begin{array}{l}1.35 \\
(6.95)^{* * *}\end{array}$ \\
\hline Cumulative privatization & & & & & $\begin{array}{l}-1.65 \\
(0.66)\end{array}$ & $\begin{array}{l}-9.67 \\
(2.66)^{* *}\end{array}$ & $\begin{array}{l}-9.92 \\
(2.87) * * *\end{array}$ \\
\hline Corporate Tax Rate & & & & & & $\begin{array}{l}-1.47 \\
(1.65)\end{array}$ & $\begin{array}{l}-1.27 \\
(1.4)\end{array}$ \\
\hline Investor Protection & & & & & & & $\begin{array}{l}0.19 \\
(1.4)\end{array}$ \\
\hline Adjusted $R^{2}$ & 0.17 & 0.35 & 0.39 & 0.69 & 0.72 & 0.7 & 0.7 \\
\hline Observations. & 78 & 78 & 78 & 72 & 64 & 49 & 49 \\
\hline
\end{tabular}

Source: Lane and Milesi-Ferretti (2003). External liberalization is an index of capital account openness. Trade openness is ratio of exports plus imports to GDP. Financial depth is ratio of liquid liabilities to GDP. Stock market capitalization is measured as a ratio to GDP. Cumulative privatization is ratio of cumulative privatization revenues to GDP. Corporate tax rate is average tax rate on corporate profits. Investor protection is a dummy taking value 1 if a country has introducted a law prohibiting insider trading and 0 otherwise. Fixed-effects panel estimation using averaged data for 1982-1985, 1986-1989, 1990-1993, 1994-1997, 1998-2001. White-corrected t-statistics in parentheses. 
Table 3: Determinants of Net Foreign Asset Positions, Industrial Countries

\begin{tabular}{lll}
\hline & $(1)$ & $(2)$ \\
& $1970-98$ & Balanced \\
\hline Log GDP per capita & 0.91 & 0.94 \\
& $(12.63)^{* *}$ & $(11.66)^{* *}$ \\
Public Debt & -0.125 & -0.18 \\
& $(3.1)^{* *}$ & $(4.54)^{* *}$ \\
Demography & 30.1 & 43.6 \\
& $(0.00)^{* *}$ & $(0.00)^{* *}$ \\
Adjusted R2 & 0.89 & 0.9 \\
Observations & 516 & 390 \\
Countries & 22 & 15 \\
\hline
\end{tabular}

Source: Lane and Milesi-Ferretti (2002a). Panel DOLS fixed-effects estimation. White-corrected t-statistics in parentheses.

Table 4: Determinants of Net Foreign Asset Positions, Developing Countries

\begin{tabular}{lll}
\hline & $(1)$ & $(2)$ \\
& $1970-98$ & Balanced \\
\hline Log GDP per capita & -0.21 & -0.26 \\
& $(4.59)^{* *}$ & $(3.55)^{* *}$ \\
Public Debt & -0.67 & -0.5 \\
& $(14.03)^{* *}$ & $(8.87)^{* *}$ \\
Demography & 28.7 & 38.7 \\
& $(0.00)^{* *}$ & $(0.00)^{* *}$ \\
Adjusted R2 & 0.83 & 0.89 \\
Observations & 779 & 416 \\
Countries & 39 & 16 \\
\hline
\end{tabular}

Source: Lane and Milesi-Ferretti (2002a). Panel DOLS fixed-effects estimation. White-corrected t-statistics in parentheses. 
Table 5: Dynamics of Net Foreign Asset Position

\begin{tabular}{lll}
\hline & $(1)$ & $(2)$ \\
\hline ECM & -0.11 *** & -0.06 \\
& $(4.1)^{* * *}$ & $(2.3)^{* *}$ \\
Adjusted $R^{2}$ & 0.28 & 0.44 \\
Observations & 539 & 849 \\
Countries & 22 & 39 \\
\hline
\end{tabular}

Source: Lane and Milesi-Ferretti (2002a). OLS estimation, t-statistics in parentheses.

Table 6: Net Foreign Assets and Real Exchange Rates

\begin{tabular}{llll}
\hline & $(1)$ & $(2)$ & $(3)$ \\
& All & Industrial & Developing \\
\hline NFA & 0.28 & 0.19 & 0.29 \\
& $(7.98)^{* * *}$ & $(3.97)^{* * *}$ & $(6.56)^{* * *}$ \\
YD & 0.14 & 0.22 & 0.14 \\
& $(3.15)^{* * *}$ & $(3.13)^{* * *}$ & $(2.57)^{* * *}$ \\
TT & 0.04 & 0.17 & 0.02 \\
& $(1.21)$ & $(4.12)^{* * *}$ & $(.51)$ \\
Adjusted $R^{2}$ & 0.52 & 0.44 & 0.42 \\
Observations & 1558 & 548 & 1010 \\
& & & \\
\hline
\end{tabular}

Source: Lane and Milesi-Ferretti (2001b). Dependent variable is CPI-based multilateral real exchange rate. NFA is ratio of net foreign assets to GDP; YD is domestic GDP relative to basket of trading partners; TT is terms oftrade. Panel fixed-effects DOLS estimation. Whitecorrected t-statistics in parentheses. 
Table 7: Rates of Return on Foreign Assets and Foreign Liabilities, 1983-1998

\begin{tabular}{lll}
\hline & $\begin{array}{l}\text { Real rate of return } \\
\text { Foreign Assets }\end{array}$ & Foreign Liabilities \\
& & \\
\hline UNITED STATES & 11.3 & 8.1 \\
UNITED KINGDOM & 6.6 & 7.1 \\
AUSTRIA & 6.5 & 8.3 \\
FRANCE & 8.5 & 8.9 \\
GERMANY & 2.9 & 4.3 \\
ITALY & 8.3 & 9.6 \\
NETHERLANDS & 5.9 & 7.3 \\
SWEDEN & 11.7 & 8.7 \\
SWITZERLAND & 6.9 & 4.2 \\
CANADA & 3.6 & 9.6 \\
JAPAN & 7 & 7.2 \\
FINLAND & 0.4 & 3.3 \\
ICELAND & 6 & 6.9 \\
SPAIN & 6.1 & 3.5 \\
AUSTRALIA & 6.1 & \\
\hline
\end{tabular}

Source: Adapted from Lane and Milesi-Ferretti (2002b). Dollar-based real rates of return.

Table 8: Determinants of Real Interest Rate Differentials

\begin{tabular}{|c|c|c|c|c|c|c|c|c|}
\hline A. Real interest rate & (1) & $(2)$ & $(3)$ & (4) & $(5)$ & $(6)$ & $(7)$ & (8) \\
\hline NFA/exports & $\begin{array}{l}-1.06 \\
(2.6)^{*}\end{array}$ & $\begin{array}{l}-0.83 \\
(2.0)^{*}\end{array}$ & $\begin{array}{l}-1.36 \\
(2.48)\end{array}$ & $\begin{array}{c}-0.91 \\
(1.66)\end{array}$ & $\begin{array}{l}-1.5 \\
(2.45)^{*}\end{array}$ & $\begin{array}{l}-1.63 \\
(2.94) * *\end{array}$ & $\begin{array}{l}-2.87 \\
(4.48) * *\end{array}$ & $\begin{array}{l}-2.81 \\
(4.65) * *\end{array}$ \\
\hline Public debt & & $\begin{array}{l}3.82 \\
(2.1)^{*}\end{array}$ & & $\begin{array}{l}7.1 \\
(3.4) * *\end{array}$ & & $\begin{array}{l}2.98 \\
(2.03) *\end{array}$ & & $\begin{array}{l}3.56 \\
(1.91) *\end{array}$ \\
\hline $\mathrm{D}(\mathrm{RER})$ & & $\begin{array}{l}0.03 \\
(1.2)\end{array}$ & & $\begin{array}{l}0.04 \\
(1.74)\end{array}$ & & $\begin{array}{l}0.02 \\
(0.9)\end{array}$ & & $\begin{array}{l}2.64 \\
(1.23)\end{array}$ \\
\hline $\begin{array}{l}\text { Adjusted } R^{2} \\
\text { Countries } \\
\text { Observations }\end{array}$ & $\begin{array}{l}0.5 \\
21 \\
462\end{array}$ & $\begin{array}{l}0.56 \\
21 \\
410\end{array}$ & $\begin{array}{l}0.36 \\
21 \\
362\end{array}$ & $\begin{array}{l}0.39 \\
21 \\
336\end{array}$ & $\begin{array}{l}0.54 \\
21 \\
442\end{array}$ & $\begin{array}{l}0.59 \\
21 \\
410\end{array}$ & $\begin{array}{l}0.43 \\
21 \\
358\end{array}$ & $\begin{array}{l}0.46 \\
21 \\
336\end{array}$ \\
\hline B. Real interest differential & (1) & $(2)$ & $(3)$ & $(4)$ & $(5)$ & $(6)$ & $(7)$ & $(8)$ \\
\hline NFA/exports & $\begin{array}{l}-2.54 \\
(5.41) * *\end{array}$ & $\begin{array}{l}-2.44 \\
(5.5)^{* *}\end{array}$ & $\begin{array}{l}-2.73 \\
(4.3)^{* *}\end{array}$ & $\begin{array}{l}-2.22 \\
(4.58) * *\end{array}$ & $\begin{array}{l}-2.57 \\
(4.03) * *\end{array}$ & $\begin{array}{l}-2.77 \\
(4.27)^{* *}\end{array}$ & $\begin{array}{l}-3.19 \\
(4.83) * *\end{array}$ & $\begin{array}{l}-3.24 \\
(5.52)\end{array}$ \\
\hline Public debt & & $\begin{array}{l}3.18 \\
(1.76)\end{array}$ & & $\begin{array}{l}7.79 \\
(4.82) * *\end{array}$ & & $\begin{array}{l}2.23 \\
(1.51)\end{array}$ & & $\begin{array}{l}3.18 \\
(1.67)\end{array}$ \\
\hline $\mathrm{D}(\mathrm{RER})$ & & $\begin{array}{l}-0.04 \\
(2.15)^{*}\end{array}$ & & $\begin{array}{c}-0.014 \\
(0.78)\end{array}$ & & $\begin{array}{l}0.012 \\
(0.54)\end{array}$ & & $\begin{array}{l}0.015 \\
(0.66)\end{array}$ \\
\hline $\begin{array}{l}\text { Adjusted } R^{2} \\
\text { Countries } \\
\text { Observations }\end{array}$ & $\begin{array}{l}0.58 \\
21 \\
423\end{array}$ & $\begin{array}{l}0.59 \\
21 \\
403\end{array}$ & $\begin{array}{l}0.6 \\
21 \\
344\end{array}$ & $\begin{array}{l}0.64 \\
21 \\
338\end{array}$ & $\begin{array}{l}0.6 \\
21 \\
416\end{array}$ & $\begin{array}{l}0.59 \\
21 \\
386\end{array}$ & $\begin{array}{l}0.63 \\
21 \\
340\end{array}$ & $\begin{array}{l}0.67 \\
21 \\
319\end{array}$ \\
\hline
\end{tabular}

Source: Lane and Milesi-Ferretti (2002a). 


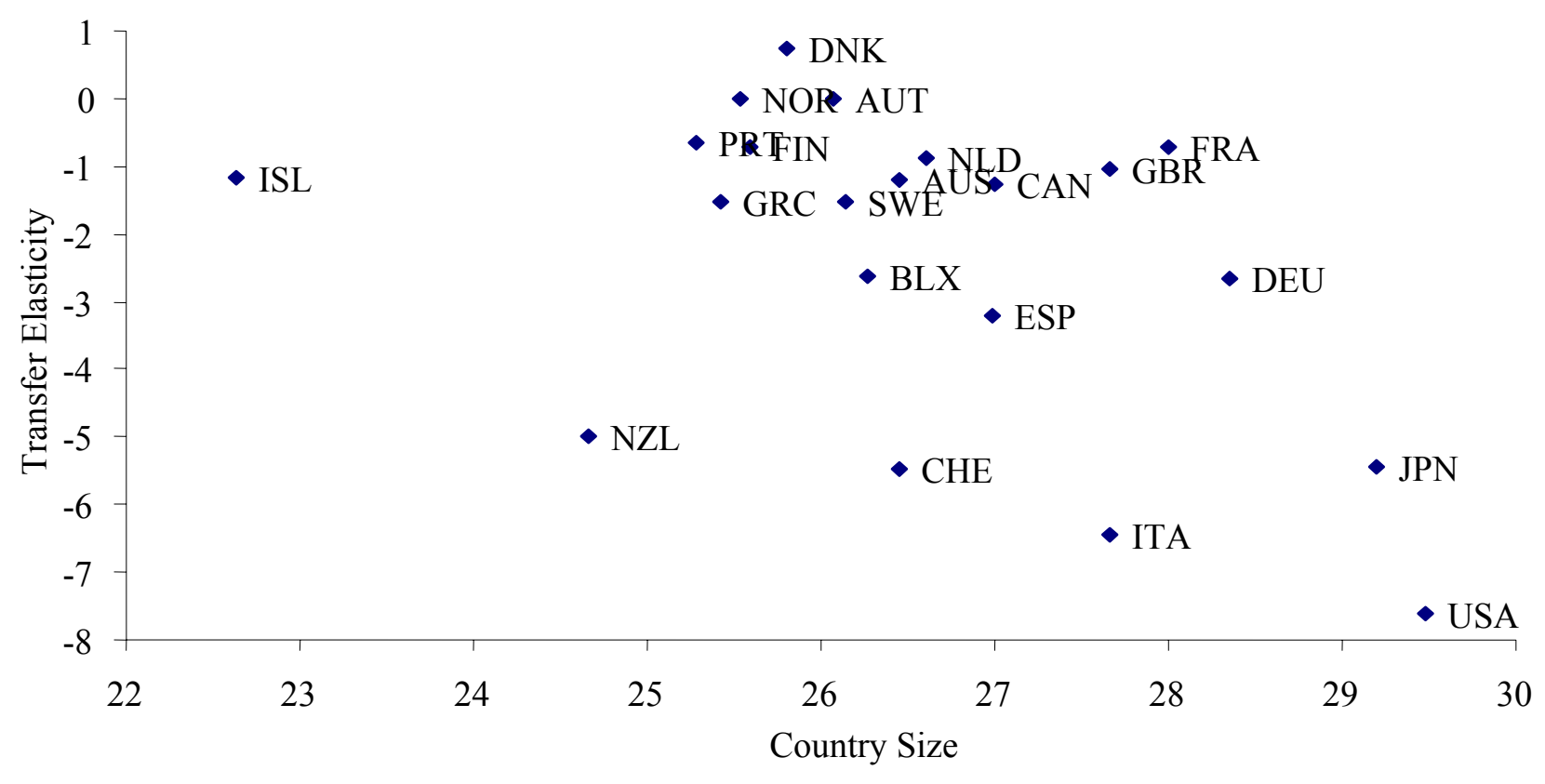

Figure 1: Source: Lane and Milesi-Ferretti (2002b). Scatter plot of estimated "transfer elasticirty" against country size. 


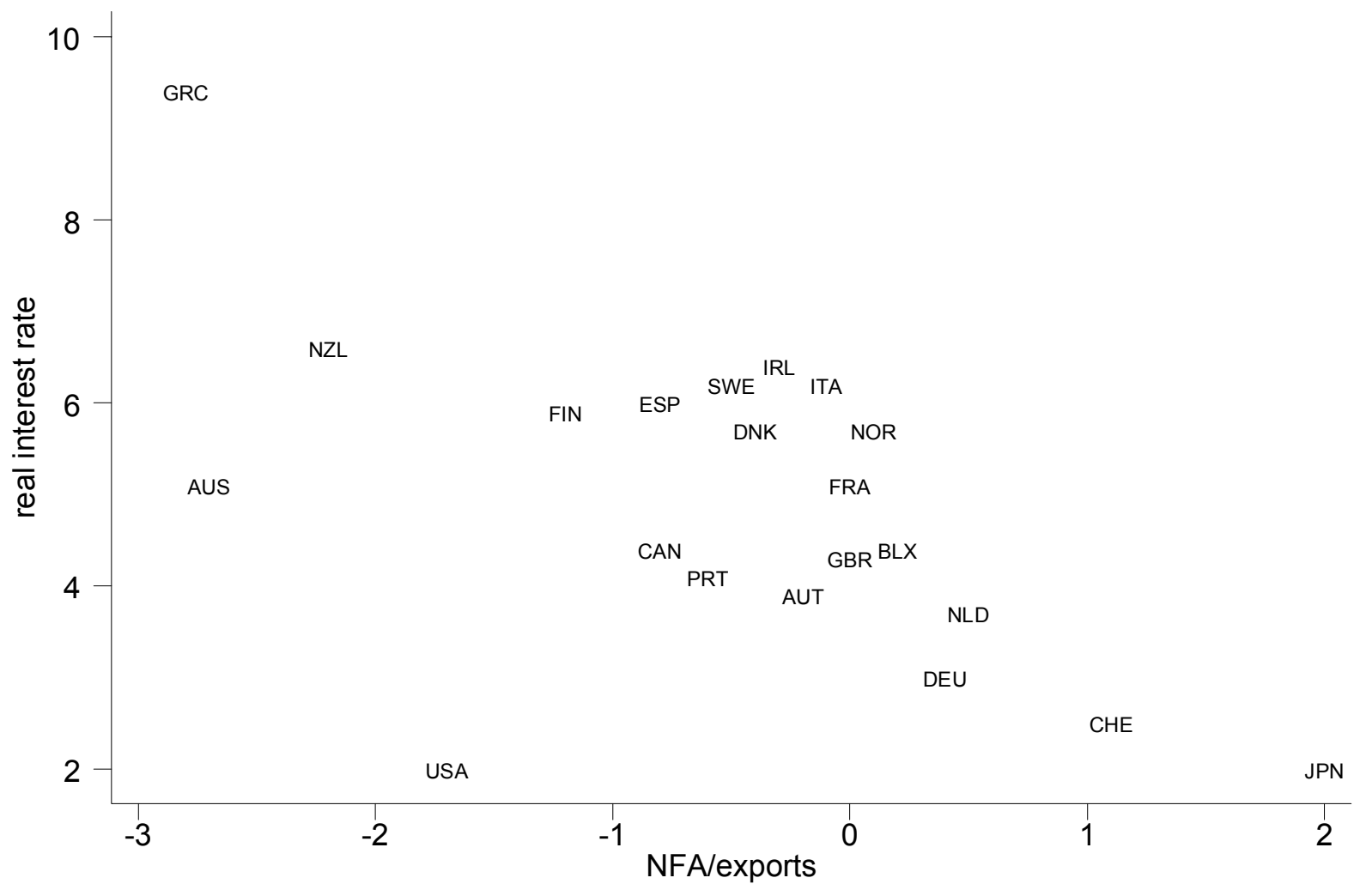

Figure 2: Source: Lane and Milesi-Ferretti (2002a). Scatter of real interest rate against ratio of net foreign assets to exports, average data over 1990-1998. 